\title{
The Practice of Islam in America: An Introduction
}

\author{
Edward Curtis IV, ed. \\ New York: New York University Press, 2017. 296 pages.
}

Since September 11, American Muslim identities, political views, sensibilities, and even private lives have been studied by academics, pollsters, government agencies, and think tank researchers. This renewed interest on the nexus of religious and national identity has produced a vast volume of publications, cross-cutting each social science discipline and thematic research area. Some are even available online, such as \#islamophobiaisracism syllabus, \#BlackIslamSyllabus and ISPU's Muslim American Experience Bibliography page.

What is often lost in this conversation, however, are the nuances that influence everyday lives of American Muslims and their practice of Islam. Situated within religious studies and Islamic studies scholarship and speaking to a broad disciplinary array, the edited volume The Practice of Islam in America: An Introduction is a much-needed contribution to the scholarship on Islam and American Muslims.

The book's editor, prolific and prominent scholar and historian of Islam in America, Edward Curtis IV, explains the goals of the book in this sentence: "This book is driven by the desire to provide clear answers to essential, and basic, questions about how observant Muslim Americans practice Islam..." (2). Importantly, the book delivers on its promise to provide a lived religion perspective (3).

While the twelve chapters in The Practice of Islam in America examine distinct practices and themes, the chapters synergize in giving voice to a lived religion perspective on American Muslims' practices. This approach helps the reader to achieve a healthy distance from the significant but often overly dominant political context that influences discourse on American Muslim life.

The book opens with an introductory chapter by Curtis, explaining the rationale and background to the project. The chapter is a good prelude to this rich volume, reflecting Curtis' years of experience working on Muslim American history and experience. For the non-specialist audience, the introductory chapter also provides a broad historical overview of American Muslim history, starting from the slave trade and stretching into contemporary Islamophobia while covering debates within the diverse American Muslim community. 
The volume is organized across four thematic parts. Each part includes three chapters, producing a rich, twelve-chapter account. Part I examines prayer and pilgrimage and includes chapters on șalāt, dhikr, and hajj. Part II explores holidays; individual chapters cover Ramadan and Eid celebrations, Ashura, and Milad/Mawlid celebrations. Part III takes the reader into the realm of life cycle rituals with chapters on birth, wedding, and funeral/ death rituals. The concluding Part IV touches on Islamic ethics and religious culture. It examines philanthropy, food practices and engagements with the Qur'an with reference to everyday practices of American Muslims.

Curtis explains in his introduction that the volume is intentional in developing a lived religion focus. Moreover, almost all authors give examples for how these practices vary in different branches of Islam (Sunni, Twelver and Isma'ili/Bohra Shi'i communities) as well as for multiple ethno-racial demographic groups that make up the deeply pluralistic Muslim American fabric. Contributors should be applauded for producing chapters that are ethnographically rich, thematically diverse, and attentive to multiple sites and dynamics.

Chapter 1 moves through multiple vignettes that involve șalāt, the Muslim ritual prayer. Rose Aslan's vivid descriptions of the lives of American Muslims and her ability to walk the reader along not only the basics of the prayer but also the nuances among individuals with diverse ethno-racial and socioeconomic backgrounds and the post-September 11 securitization of șalät is refreshing. Rosemary R. Corbett's chapter on dhikr- "meditative and sometimes joyous religious litanies," to use the definition offered by Curtis in the introductory chapter (6) - is a comparative study of three related groups, each springing from the Turkish Halveti Cerrahi order. The historical account around the creation of these groups is helpful especially because one of these figures, Tosun Bayrak of the Spring Valley Halveti Cerrahi order, recently passed away. In the next chapter, Hussein Rashid skillfully walks the reader through the meaning, rites, and politico-economic realities surrounding hajj, the pilgrimage to Mecca in Saudia Arabia. His chapter helps to familiarize the readers with complexities of hajj.

Part II of the book begins with Jackleen Salem's nuanced and vivid account of Ramadan, Eid al-Fitr, and Eid al-Adha. In testament to the volume's attention to inclusivity, Michael Muhammad Knight's chapter on Ashura is a vivid and informative account of this most popular Shi' $i$ commemoration. This chapter is less ethnographically driven than other chapters preceding it, perhaps to the advantage of the common reader who learns a great deal about early Muslim history and the background to the 
Sunni-Shi'i split. The same is true also for Marcia Hermansen's chapter on Milad/Mawlid celebrations recognizing Prophet Muhammad's birth. The chapter strikes a balance between academic information on the subject and a thick description of these ceremonies. She provides a superb account of major debates and disagreements within the Muslim community surrounding these celebrations for the benefit of the uninitiated reader.

In the first chapter of Part III, Maria Curtis explores birth rituals ranging from baby-showers to naming a child to postpartum complexities faced by moms within the American Muslim community. Her chapter is noteworthy in producing a much-needed addition to these underexplored topics.

Juliane Hammer's chapter on weddings is an exploration of not only ceremonial aspects of marriage but also legal approaches to marriage in America through a rich ethnographic account of three distinct weddings. She gives due attention to textual and Quranic interpretations on love and mercy by American Muslims. Her chapter is among those that provide the common reader with a nuanced view of the scholarship on the theme that is under exploration. The same is true for Amir Hussain's chapter on Muslim funerals. Speaking from within a few funeral processions in southern California, as well as a brief description of the funeral ceremony of Muhammad Ali, Hussain explores the rites of death and burial in the American Muslim landscape.

The first chapter of Part IV, by Danielle Witman Abraham, examines philanthropy and social giving in the American Muslim community. The chapter explains the norms in Sunii and Shi'i communities, including concerns about domestic vs. international giving. Chapter 11, by Magfirat Dahlan, delves into American Muslims' food consumption choices. She explores the fluid categories of permissible and impermissible food as well as ethical vs. non-ethical food as perceived by her respondents. The final chapter of the book is by Mona Ali and focuses on the Qur'an and how American Muslims engage with Islam's holy book. Her approach provides a concise and effective summary of the Qur'an's role in life cycles, identity formation and internal conversations among American Muslims.

While the individual chapters' focus on specific contexts and ethnographic accounts is very helpful, some chapters leave the reader with a sense of incompleteness due to the brief attempt to cram information on the broader context in the last two pages of each chapter. For example, in Chapter 1, Rose Aslan invokes the American Muslim debate around creating gender equity in mosques and the third space wave but cannot do 
justice to the multifaceted conversations and developments around this issue. Chapter 4 by Jackleen Salem also suffers from trying to deliver too much. Salem's concluding section, "Eid as an American Holiday," fails to mention the heated debates that defined the "White House Iftar" dinners during President Obama's presidency. These kinds of omissions create a kind of wedge between the complexities that arise in the everyday practice of Islam and the volume's broader reflections. Chapter 9, by Amir Hussain, details Muhammad Ali's funeral but does not fully engage with the debates and choices that marked the funeral.

One wonders too if inclusion of other dhikr practices adapted by American Muslim followers of the Tijaniyya or the Ba'Alawi sufi networks could have been helpful to give voice to dhikr practice in Chapter 2, outside the Halveti Jerrahi context. Another theme that is neglected lies in the chapter on philanthropy, which does not mention what are often heated debates within American Muslim communities on the jurisprudence (fiqh) of giving to non-Muslims as well as whether certain service organizations (such as those serving students or social justice needs) are zakāt-eligible.

There are practices that are left out as well. Du'a Kumayl, practiced by Shi' i Muslims on Thursday evenings similar to mawlid ceremonies, is not mentioned in the text. It would have been enriching to include this practice of reading a prayer that is traced to Prophet Muhammad's cousin and one of the four great caliphs, Imam Ali.

Finally, the choice to not cite online resources with their full web addresses seems like an odd choice for a volume this rich in content. The lack of a full pathway in many instances makes it difficult for researchers to access information.

These slight omissions notwithstanding, The Practice of Islam in America: An Introduction is a great resource for instructors to use in introductory courses in religious studies and American Muslim studies programs, as well as a good supplementary text for anyone teaching Islam in interfaith contexts. It delivers on its promise to provide rich narratives on what Islam looks like as a lived religion in America. It is highly relevant for those teaching not only on Islam but also on religion generally. The editor as well as the authors deserve recognition for producing a nuanced and insightful volume. 